\title{
Environmental Management Compliance, Law and Policy Regimes in Developing Countries: A Review of the Zambian Case
}

\author{
Cuthbert Casey Makondo, ${ }^{1,}$, Sydney Sichilima ${ }^{1}$, Matthews Silondwa ${ }^{1}$, Richard Sikazwe ${ }^{1}$, \\ Lombe Maiba $^{1}$, Chawezi Longwe ${ }^{1}$, Yvonne Chiliboyi ${ }^{2}$ \\ ${ }^{1}$ Environmental Engineering Department, Copperbelt University, Kitwe, Zambia \\ ${ }^{2}$ Institute for Water Research, Rhodes University, Grahamstown, Republic of South Africa
}

\section{Email address:}

SimplyCuthbert@live.co.uk (C. C. Makondo),nsichilima@gmail.com (S. Sichilima),msilondwa2@gmail.com (M. Silondwa), maibalombe@yahoo.com (L. Maiba), Richard.sikazwe@yahoo.com (R. Sikazwe), chalongwe@yahoo.co.uk (C. Longwe), Yvonne.chiliboyi@gmail.com (Y. Chiliboyi)

\section{To cite this article:}

Cuthbert Casey Makondo, Sydney Sichilima, Matthews Silondwa, Richard Sikazwe, Lombe Maiba, Chawezi Longwe, Yvonne Chiliboyi. Environmental Management Compliance, Law and Policy Regimes in Developing Countries: A Review of the Zambian Case. International Journal of Environmental Protection and Policy. Vol. 3, No. 4, 2015, pp. 79-87. doi: 10.11648/j.ijepp.20150304.11

\begin{abstract}
This paper is a review of environmental management compliance of the extractive industry; particularly mining in Zambia and the government's commitment to environmental protection in view of sustainable development . The main objective of this work was to review industrial compliance against Zambia's environmental legal regime for the period between 2009 and 2014, track environmental policy development, its implementation within the institutional functional framework in view of precautionary principle, polluter pays principle and sustainability. The authors concluded that while the environmental legal framework may be considered relatively new compared to developed nations like United Kingdom, it dates back to the 1970s and is comparable in terms of strength, to that of developed nations. However, there are many challenges regarding effective implementation. Thus, although there are many stiffer and tougher regulations enacted in Zambia (to a point where some advocates of neo-classical frontiers economics have criticized Zambia as slowly introducing one-more among the most highly regulated environmental sectors in the world, deterring development) the authors concluded that implementation was a huge challenge: implementation of Zambia's environmental regulatory regime faces wide range of problems, from a highly centralized financial and decision-making system and budgetary allocation of negligible size, to lack of appropriate tools, equipment and personnel technical capacity. It was found that while the environmental regulations have been further stiffened around 2011-2013; compliance of mining companies was lagging behind. This was evidenced by failure of 8 in 10 mining firms to submit periodic reports as per regulatory conditions on their permits. Cases of discharging and disposing of hazardous waste to gain savings from the expenses that would otherwise arise through normal disposal procedures still exist. The authors concluded that while new and stronger measures have been put in place by government to ensure that the environmental degradation caused by mining and other extractive industry activities are adequately managed, the measures are not working effectively. These findings are consistent with the findings of the 2014 Auditor General's Report. It was clear that co-ordination within the government's regulatory institutional framework with interacting mandates was weak, while the selective nature on the application of the Environmental Impact Assessment (EIA) regulations was demeaning environmental protection and socio-economic justice.
\end{abstract}

Keywords: Extractive Industry, Triple-Bottom-Line, Sustainability, Environmental Management, Compliance, Law and Policy

\section{Introduction}

In developing countries where economic development is driven mostly by the extractive industry, terms such as "environmental management and sustainability" and "triple-bottom-line" are relatively new concepts $[1,2]$. In these nations, economic growth concerns have tended to override environmental sustainability considerations [2, 3, 4]. However, with an increased global concern following 
Rio-1992 (the first Earth Summit on Environment and Development) issues of sustainable development (the idea that development is threefold, encompassing-environmental, social and economic balance or triple-bottom-line) have gained understanding in resource management practices [4]. With a rapid growth of the third-sector organizations in the 1990s demanding environmental justice and green growth from governments through tough industrial regulation, stringent environmental regulatory regimes and reorganizations of institutional framework arrangements became inevitable in most nations. In Africa however, existing environmental regulatory regimes have been cited as weak in many studies [1, 3]. And because of this perception, some multinationals operating in the extractive industry have been forced by International Financing Corporations (IFC; e.g., Citi-group and World Bank) to implement initiatives considered 'good practice' such as equator principles when implementing IFC financed projects costing over US\$4m [5]. However, equator principles have had their weaknesses which are not part of this paper.

After agriculture, mining in Zambia is probably the second oldest extractive industry. It has taken place for centuries; starting with rudimental activities recorded in 1880 s to relatively larger scale artisanry 48 years later in 1902 around Kabwe-kamukuba, and then to the first commercialized operation of 1928. Mining has undeniably played a central role in Zambia's socio-economic development across all political regimes, albeit its associated environmental effects [6]. The mining of copper particularly, has been the most significant mineral resource with ubiquitous deposits in two main areas of the country, namely; Copperbelt and North-western Provinces. Other mining projects include coal, uranium and nickel in Southern Province and gemstones in many parts of the country. The sector has gone through three main phases of ownership: first, private ownership under a colonial administration prior to political independence in 1964 , then national ownership post-independence in 1971under the Kaunda government, until the re-privatization of the 1990s under the Chiluba government [6].

During mines privatization in 1990s, with the demands of due-diligent audits, the burden of environmental liabilities was shouldered squarely by the government before new mine owners' formalized acquisitions of mine facilities across Copperbelt. With the help of the World Bank, and Nordic Development Fund, the Zambian government initiated the Copperbelt Environment Project (CEP) worth about US\$62M, to address all former mining liabilities in the Country. By 2003, CEP was launched to address among others, strengthening the regulatory capacity of ECZ and Mine Safety Department (MSD). One of the most successive stories of CEP was the acquisition of various environmental monitoring equipments; and the creation of an Environmental Protection Fund (EPF) to ease future rehabilitation funding mechanisms by operationalizing environmental rehabilitation in view of polluter pays principle. Under this fund, mining liabilities of current and future operations would be addressed using these pool funds. Consequently, all mining firms were required to contribute certain amount of money annually commensurate to their foreseeable environmental liabilities. EPF is still operational today, albeit difficulties in costing environmental liabilities of ongoing mining activities.

While the positive side of mining has been greatly felt and more often openly discussed, the negative legacy; a much dark side of mining had remained secret and only known to few medical doctors and environmentalists. Thanks to the growth of the third sector organizations such as non-governmental organizations and investigative journalism: it is now public knowledge and clearly understood by many that mining in Zambia have had serious negative legacies; beginning with lead poisoning:-the silent killer in Kabwe, through sulphur-dioxide (locally known as senta) the "lung-eating" gas in Mufulira and Kitwe West, to the poorly managed radioactive materials present in Kitwe's Mindolo area, and from acidified surface water and ground water emanating from in-situ leaching and acid mine drainage challenges, to heavy metals contamination and siltation loading of streams, and deliberate hazardous chemical waste disposals on the Copperbelt due to an unethical business practices of some companies. All these practices have significant cumulative impacts not only on receptor environmental media quality and alterations of ecological functionalities, but also on public health and safety especially on the Copperbelt, and Kabwe. This is likely to be the same problem in the Northwestern Zambia where some of the world's largest copper smelting facilities have now been commissioned. Some cases of firms of multinational standing have been prosecuted by Zambia Environmental Management Agency (ZEMA), but with such multinationals, solicitation and lobbying usually results in reversal of judgments against conviction on their offences. Meanwhile, the lives of thousands of people remain threatened from toxic chemical discharge into local streams, to ambient air emissions of oxides of sulphur $\left(\mathrm{SO}_{\mathrm{x}}\right)$ of concentrations ranging between 500 and $1000 \mu \mathrm{gm}^{-3}$.

\section{Methodology and Limitations}

This paper is a review of environmental management compliance of the mining sector in Zambia, and the government's commitment to environmental protection in view of sustainable development. It is based on policy tracking and subsequent field investigation works that spanned over 5 years from 2009 to 2014. The methods employed included regular sampling of stream water and analyzing for heavy metal levels using atomic absorption spectrometry method. Sampling at one specific point of the stream (for all the streams) investigated was done quarterly per year, for a five year period. At the end of each year, quarterly concentration readings were averaged to obtain an annual mean concentration. The water quality data (average data) was then compared with regulatory limits to measure level of compliance. Field observations and conducting simple interviews with 10 mines was part of the methodology to gauge commitment. Company documents in public domain like Environmental and Social Management Plans (ESMPs) in 
the EIA reports were also evaluated.

However, some of the limitations with this work include loss of individual sample signatures (actual figures) in the generalization or averaging process: averages are highly influenced by extreme values. Conversely, though sampling was done on a regular interval, results may not reflect an accurate picture. Other environmental media, e.g., air quality assessment and soil heavy metal analysis was not done due to lack of equipment for the former, and due to complexity of procedures for gaining access to mines facilities and the size of the study area for the latter.

\section{The Environmental Legal Framework}

Environmental regulation in Zambia dates back to 1970 when the Natural Resources Act was passed aiming at nature conservation. This was followed by Game Parks and Birds Act a year later whose objective was to conserve wildlife. In 1987, The Zambezi River Authority Act, targeting shared river systems bordering Zambia and Zimbabwe was enacted. Table 1 below shows specifically important pieces of environmental regulations. In terms of heritage conservation, this was recognized in 1989 when the Heritage Conservation Act was passed to preserve local culture, shrines, monuments and specific sites of national significance [7].

In spite of the National Conservation Strategy (NCS) being in place at this stage however, the cost of environmental liabilities and the negative legacy of mining were specifically felt at privatization after due-diligent audits were conducted in 1990s. It was at this time that the first need for clearer environmental legislation was recognized [7]. Consequently, with works already initiated by the Kaunda government from the recommendation of the NCS, the Environmental Protection and Pollution Control Bill (EPPCB) was passed and enacted by parliament in 1990 as Environmental Protection and Pollution Control Act- EPPCA (CAP 204).

The EPPCA provided for the establishment of the Environmental Council of Zambia (ECZ) in 1992 which assumed an advisory role to the government on environmental matters. Its other mandate was to issue environmental permits and monitor compliance of extractive and processing industries; draw up new regulations as necessary and enforce such on environmental media quality while educating the general public on matters of environmental and public health. With a view to building up on the EPPCA, recognizing that every citizen has a right to health and clean environment, government through ECZ formulated the National Conservation Action Plan to provide for mandatory appraisals for all new major projects and existing major ones that would need upgrading? This was going to be done through a precautionary principle tool provision - Environmental Impact Assessment (EIA), while providing for objective public participation in the process. In 1997, Statutory Instrument (SI) No. 28 (Environmental Impact Assessment) Regulations was passed to govern the EIA process. Under these regulations, it is an offence to implement any project categorized under first and second schedules of these regulations. Penalty for violating these regulations can be at very minimum US $\$ 45,000$ or a three-year-jail term; even both depending on the gravity of the offence [7].

In 2011, the Environmental Management Act No. 12 repealed the EPPCA of 1990. By this Act, ECZ changed its name to Zambia Environmental Management Agency (ZEMA) but with exactly the same mandate, only with more powers to prosecute environmental offences. The Act also provided for the upgrading of all regulations that complemented EPPCA. In 2013, all the EPPCA regulations were upgraded by SI No.112-Environmental Management (Licensing) Regulations with yet stiffer penalties upon conviction of environmental violation. Table 1 shows all the most important regulations and acts and policies in Zambian [7].

Table 1. Zambia's Key Pieces of Environmental Legislation and Regulations.

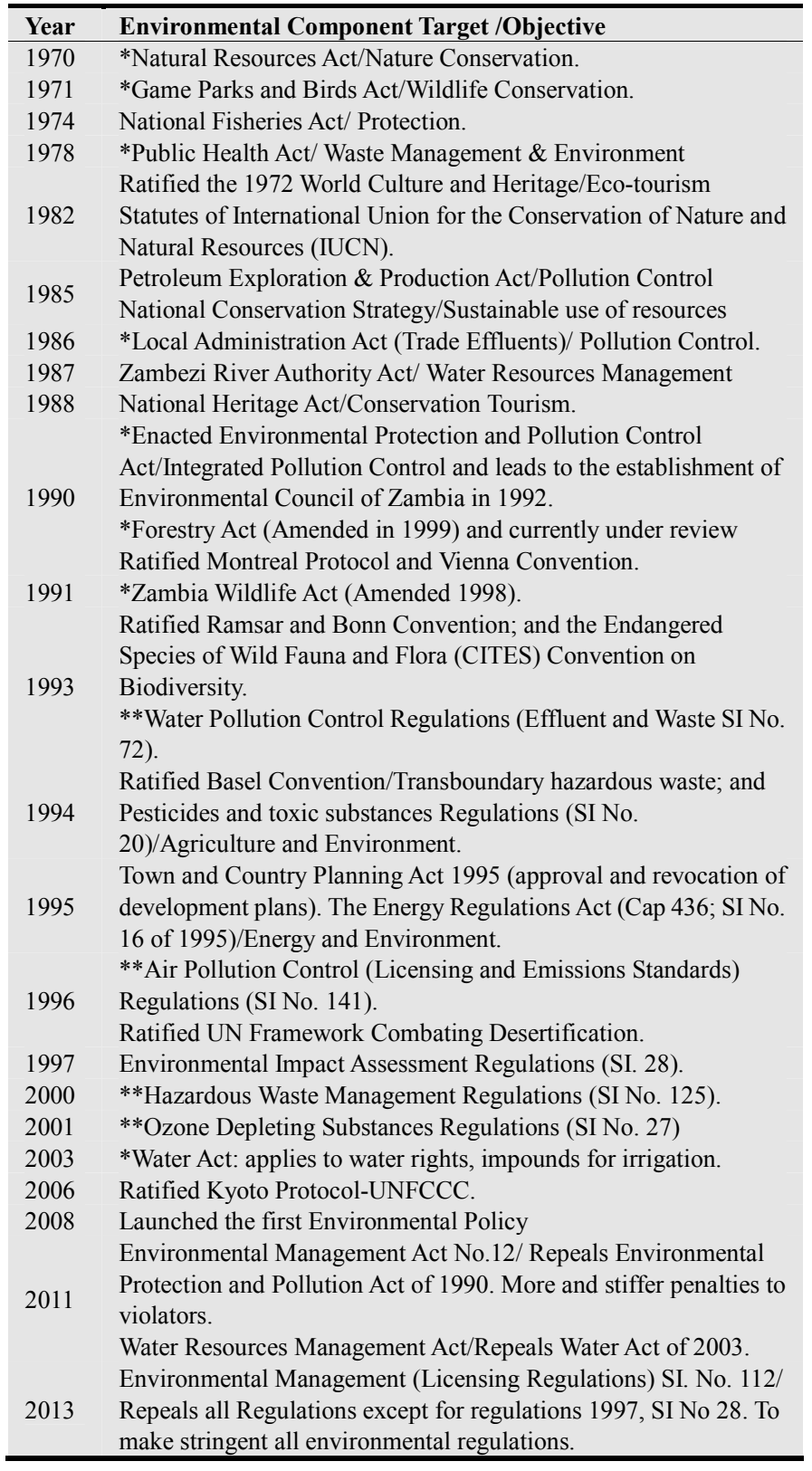

*Repealed Acts or regulations. ** Repealed specifically by Environmental Management (Licensing Regulations) SI. No. 112 of 2013. 


\section{Institutional Framework}

From being Ministry of Environment, Natural Resources and Tourism in 1991, the ministry under which environmental protection falls has changed its name many times. At publication date of this paper, environmental protection fell under the Ministry of Lands, Natural Resources and Environmental Protection, from Ministry of Mines, Energy and Water Development which used to combine environment, mining, lands, energy and water development, a scenario that brought considerable administrative challenges making it the home-mark of work replication, bureaucracy and inefficiency. Essentially, policy synchronization proved difficult and cases of opposing objectives were not uncommon under this arrangement.

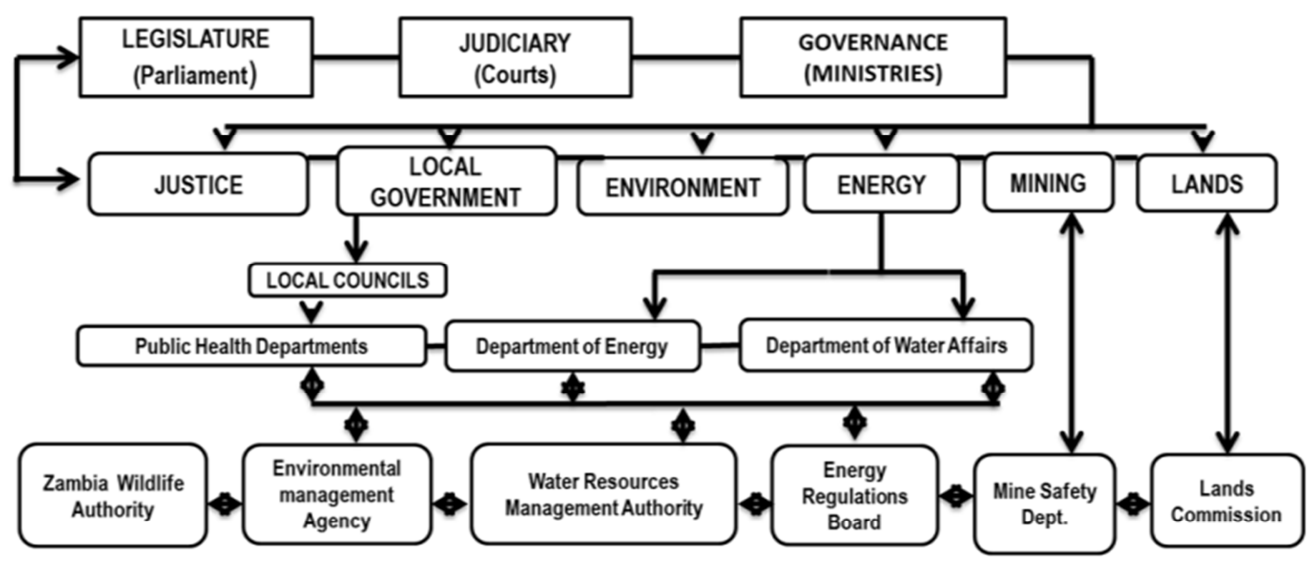

NOTE : Environment, Lands, Mining, Energy and Water : now operating as one ministry

Figure 1. Simplified Environmental Governance Institutional Framework

Figure 1 (above) illustrates the simplified governance structure. At the top are the supreme organs of governance, parliament, judiciary and ministries. Ministries have different departments below them and under these ministries are various statutory organs with overarching mandates. The Zambia Environmental Agency (ZEMA) is one of these organs working in coordination with others e.g. Zambia Wildlife Authority on wildlife and natural resourced conservation, and with Water Resources Authority and Department of Water Affairs on water access rights, ground and surface water quality preservation. ZEMA also works with local councils on public health and safety while working with Lands on land matters for industrial project location approvals. It is this complex co-ordination that slows down information flows between organs of interacting mandates that was found to be weak. Lack of up-to-date information systems for easy decision making processes has made informed decision making difficult.

\section{Findings/Results Discussion}

Heavy metal concentrations results are shown in Table 2 and graphic presentation in Figure 3 below. These results indicate that cobalt $(\mathrm{Co})$ concentrations were far too high in Uchi stream, followed by Mindolo and upper Kafue in Chingola ranging from 9 to 32 times more than the regulatory limits of $1 \mathrm{mgL}^{-1}$ (Table 2 and Figure 3). Manganese (Mn) was also high and above regulatory limits of $1 \mathrm{mgL}^{-1}$ in all the streams investigated and was found to be at least 1.5 , and at most 4 times more than regulatory limits. However, cadmium (Cd) and arsenic (As) were low with the latter generally below detectable limits in all the streams investigated and when it was detectable; it was found to be below the regulatory limit of $0.05 \mathrm{mgL}^{-1}$ and thus raised no concerns. Cadmium though found in all the streams investigated, it was below regulatory limits of $0.5 \mathrm{mgL}^{-1}$ and thus raised no concerns as well. Lead $(\mathrm{Pb})$ presence was generally detected but like arsenic, it was below the regulatory limit of $0.5 \mathrm{mgL}^{-1}$ and thus raised no concerns too. Copper was generally below regulatory limits of $1.5 \mathrm{mgL}^{-1}$. Potential of Hydrogen $(\mathrm{pH})$ was within acceptable limits for Uchi, Mindolo, and down Kafue streams at Sabina, except for the upper Kafue in Chingola were it was averaging between 3.4 and 5.5 .

Findings on institutional framework revealed a complex co-ordination system that completely slows down decision making-process, due to poor information flow between organs of interacting mandates. It was found that a lack of up-to-date information system for easy decision making process has made informed decision making process difficult if not impossible. Government is aware as evidenced by the continued relocation of the environmental protection component from one ministry to another. This has delayed implementation of environmental agendas as the department involved is continuously under restructuring with shifting reporting arrangements almost annually.

The capacity of statutory agencies (ZEMA and MSD particularly) is still lacking though slightly improved compared to 5 years ago. The technical capacity of personnel is still inadequate, though there are improvements. Highly trained personnel who include lawyers and inspectors with police training background in criminal investigation now handle some of the most sophisticated environmental 
pollution cases. However, due to poor salaries, most of the young ones leave for corporate environmental positions as soon as they get experienced. Conversely, while the Environmental Protection Fund (EPF) has been cited as one of the most successive stories of the Copperbelt Environment Project (CEP), findings revealed that there are still some challenges regarding its ways of valuing environmental liabilities of mining companies. For instance, it was found that the initial methods which were used at its inception were discarded soon after a year or two after the realization of gross weaknesses. New methods now use quantum based determinations of liabilities. However, even quantum based determinants have been criticized by some environmentalists of under-valuing the liabilities of mining companies.

With regards to the CEP, due to the procedures of the World Bank the project suffered massive bureaucracy financial disbursement delays. Instead of taking only 5 years to address environmental liabilities from former mining activities, the project took 8 years, and still never exhausted the funds, and never did land rehabilitation works in some locations like Kabwe for instance. Today, Kabwe is still ranked among the top-ten most polluted spots on the planet [10].

On EIA process and its implementation, it was found not to be effective. Challenges range from poor public consultation, weak stakeholder engagement to weak EIA out-put documents. The Environmental Impact Statements (EIS) lack scientific rigor. In worst case scenarios, some EIS reports were found to have "copy and paste" problem, from other EIS documents done by same consultants. These documents would have exactly the same errors, discussing the same locations, but were for separate project areas which were not only in different locations, but also for different developers. Other than suggesting that there is far too much mediocrity in the way EISs are being done, this also provides evidence that there are unqualified consultants doing these works. These findings are consistent with those of [10]. Apart from poor EIS works, there is further evidence that the EIA application is selective. Government funded, or government backed projects were found to be 3-4 times more likely to be approved without a thorough EIA processes. There are cases where EIAs for government owned projects have been done in retrospect, with the project already on commissioning phase. The other challenge identified on the EIA practice is the lack of post decision follow-ups by EIA approving body, ZEMA. There are no follow-ups to see whether the ESMP provided in the EIS is being followed by the project proponent, or whether the predicted impacts actually occurred. Post-decision monitoring audits are very useful in improving future EIA quality. Consequently, it can be argued that an EIA process in Zambia has simply become a weak academic exercise with little to offer on the precautionary and polluter pays principles, other than being merely used to seek stamps of approval from the authorities.

Table 2. Water samples and associated levels of different parameters of tributaries of the Kafue River.

\begin{tabular}{|c|c|c|c|c|c|c|c|}
\hline \multirow{2}{*}{$\begin{array}{l}\text { Sampling period \& name of stream } \\
\text { Uchi Stream (Kitwe South) }\end{array}$} & \multicolumn{6}{|c|}{ Annual mean concentrations } & \multirow[b]{2}{*}{$\begin{array}{l}\text { As Conc. } \\
\text { mgL-1 }\end{array}$} \\
\hline & pH & Cu Conc. mgL-1 & Pb Conc. mgL-1 & $\begin{array}{l}\text { Mn Conc. } \\
\text { mgL-1 }\end{array}$ & $\begin{array}{l}\text { Cd Conc. } \\
\text { mgL-1 }\end{array}$ & $\begin{array}{l}\text { Co Conc. } \\
\text { mgL-1 }\end{array}$ & \\
\hline Year 1 & 5.10 & 0.61 & 0.02 & 4.45 & 0.02 & 9.61 & $<0.01$ \\
\hline Year 2 & 6.20 & 0.40 & 0.02 & 2.61 & 0.01 & 28.30 & 0.02 \\
\hline Year 3 & 5.57 & 0.43 & 0.07 & 2.10 & 0.03 & 12.00 & 0.01 \\
\hline Year 4 & 6.37 & 0.37 & 0.01 & 3.13 & 0.05 & 22.10 & $<0.01$ \\
\hline Year 5 & 7.02 & 0.34 & 0.11 & 4.30 & $<0.01$ & 32.00 & $<0.01$ \\
\hline \multicolumn{8}{|l|}{ Mindolo Stream (Kitwe Northwest) } \\
\hline Year 1 & 5.20 & 0.43 & 0.01 & 1.37 & 0.03 & 4.28 & 0.00 \\
\hline Year 2 & 6.00 & 0.61 & 0.03 & 3.21 & 0.01 & 1.96 & 0.00 \\
\hline Year 3 & 7.36 & 0.55 & 0.02 & 3.51 & 0.04 & 2.13 & $<0.01$ \\
\hline Year 4 & 7.12 & 0.43 & 0.04 & 2.11 & 0.01 & 1.91 & $<0.01$ \\
\hline \multicolumn{8}{|l|}{ Up Kafue River (Chingola Northwest) } \\
\hline Year 1 & 3.40 & 0.52 & 0.13 & 1.78 & 0.04 & 1.87 & 0.02 \\
\hline Year 2 & 4.50 & 0.31 & 0.10 & 3.01 & 0.01 & 2.21 & 0.01 \\
\hline Year 3 & 4.02 & 0.32 & 0.01 & 1.98 & 0.03 & 1.99 & 0.01 \\
\hline Year 4 & 7.32 & 0.04 & 0.16 & 1.74 & 0.02 & 1.08 & 0.00 \\
\hline Year 5 & 5.50 & 0.05 & 0.11 & 1.21 & $<0.01$ & 1.71 & $<0.01$ \\
\hline \multicolumn{8}{|l|}{ Dwn Kafue River (Sabina-Kitwe North) } \\
\hline Year 1 & 6.50 & 0.71 & 0.12 & 1.61 & 0.01 & 0.81 & 0.01 \\
\hline Year 2 & 7.20 & 0.57 & 0.08 & 1.33 & $<0.01$ & 0.12 & 0.02 \\
\hline Year 3 & 7.10 & 0.98 & 0.06 & 1.62 & 0.02 & 0.13 & 0.01 \\
\hline Year 4 & 7.30 & 0.59 & 0.31 & 0.67 & 0.01 & 0.34 & 0.01 \\
\hline Year 5 & 6.96 & 0.65 & 0.01 & 0.92 & 0.01 & 0.51 & $<0.01$ \\
\hline
\end{tabular}



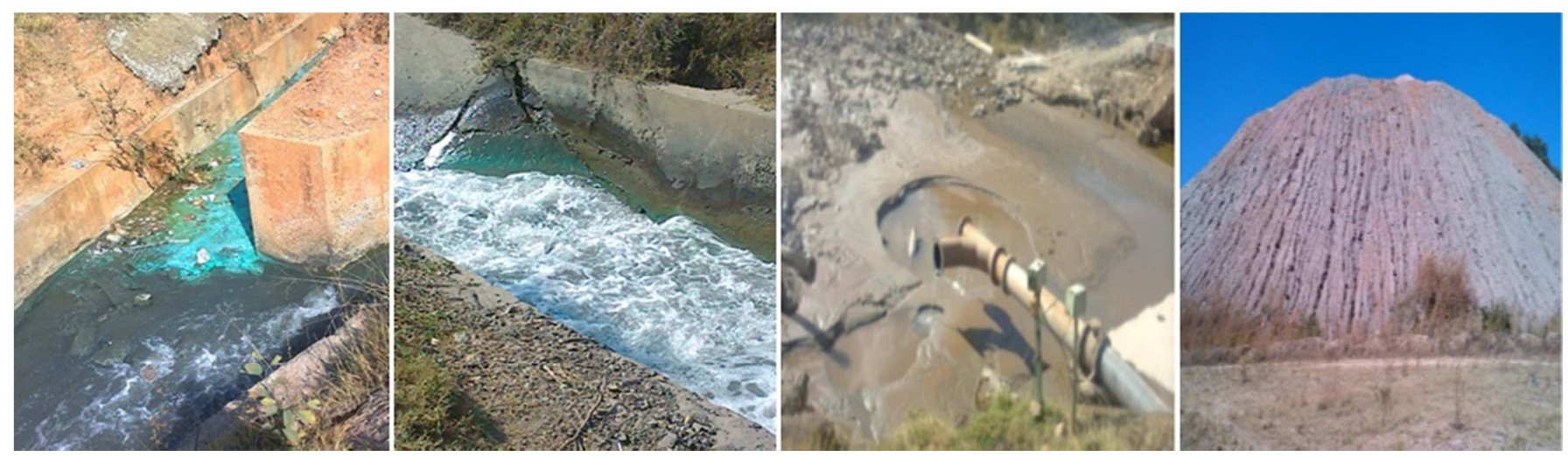

Figure 2. Low pH wastewater effluent discharging with heavy metal precipitates, silt and sedimentation, and erosion of un-vegetated dumps.

Table 3. Government Budgetary Allocation for Environmental Protection in the last decade. Source: Ministry of Finance, http://www.mofnp.gov.zm/.

\begin{tabular}{lllllllllll}
\hline Year & $\mathbf{2 0 0 6}$ & $\mathbf{2 0 0 7}$ & $\mathbf{2 0 0 8}$ & $\mathbf{2 0 0 9}$ & $\mathbf{2 0 1 0}$ & $\mathbf{2 0 1 1}$ & $\mathbf{2 0 1 2}$ & $\mathbf{2 0 1 3}$ & $\mathbf{2 0 1 4}$ & $\mathbf{2 0 1 5}$ \\
\hline Amount ZMW'Million * & 43.3 & 103.3 & 95.7 & 117.3 & 148.5 & 121.3 & 31.8 & 74.2 & 165.2 & 174.96 \\
\% of Total Budget & 0.004 & 0.009 & 0.007 & 0.008 & 0.009 & 0.006 & 0.001 & 0.002 & 0.004 & 0.004 \\
Total Budget ZMW'Million* & $10,236.8$ & $12,034.4$ & $13,761.4$ & 15,279 & $16,717.8$ & $20,537.4$ & $27,698.3$ & $32,212.2$ & 42,682 & $46,666.56$ \\
\hline
\end{tabular}

*US\$1=ZMW7.3 (Bank of Zambia. http://www.boz.zm)

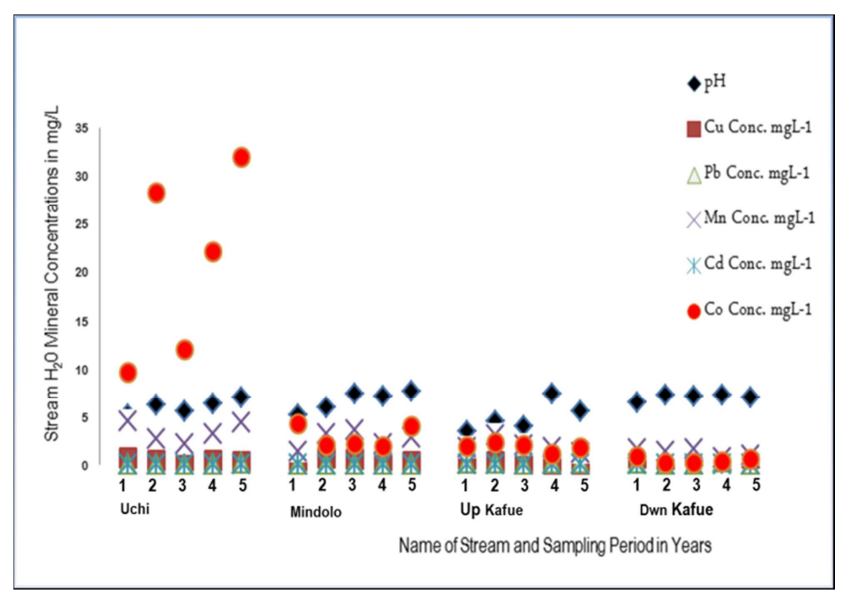

Figure 3. Graphic Presentation of stream water heavy metal concentrations.

Another interesting finding was the absence of environmental management systems certification: no mining company in Zambia is ISO 14001 certified, but most of them are in the planning phase to have systems put in place. With such lack of commitment to good practice environmental management systems, it is easy to argue that the mining industry in Zambia cannot comply voluntarily: it cannot drive the environmental protection agenda without being forced to, through regulation. In other words, the driving factor in this industry, it can be argued; is a single bottom-lime: - profit. This is not new: other studies have revealed a similar behavior $[8,9,10,11,12,13,14,15,16,17]$. In Zambia however, there is further evidence of extreme profit loving, as exhibited by some companies' false profit declarations, and price transfer systems as a means through which to evade taxes. Some firms also threaten government of abandoning projects and use local nationals' job losses as a means to maintain status quo whenever there are proposed production output based tax changes in the sector. One can argue that there is no commitment to the triple-bottom-line, since the societal and environmental wellbeing has been receiving least attention. These findings are consistent with some of those by [10].This was evidenced by the fact that nearly all mining companies $(80 \%)$ are still heavily relying on environmental management plans that were done more than 10 years ago, coupled with low impact "smoke screen" social corporate responsibility programs. Ideally, Environmental and Social Management Plans (ESMPs) must be revised every 3 years as loosely provided for in the EIA regulations. However, because this provision refers specifically to a non-developed project whose EIS may have been approved but just never got implemented within a three-year-period after approval, then a new EIA must be done with a new ESMP. And because it so unclear on the already existing ESMPs of operating firms, companies may almost always find ways to exploit such vague regulations.

Government commitment to environmental protection in monetary terms has been displayed in Table 3. As can be seen, the allocation is far less than $1 \%$ of the total national budget. It is the least funded sector in Zambia. Recreation, Culture and Religion is the second least funded sector and gets about 2.5 times more than the environmental sector budget. Much of the funds to the environmental sector come from donor countries to fund training and personnel capacity building programs, and for tools and equipment acquisition. The lack of proper funding obviously has a huge bearing on the monitoring and the economics of law enforcement in the sector.

\section{Conclusion}

Although the information collected over the last five years has shown that environmental compliance is improving generally except for a few incidences, such as the acid levels in the Kafue tributaries, and cobalt levels around Kitwe streams; mining companies are generally not complying with the environmental regulations and environmental licensing conditions set by Government. This was evidenced by failure 
of firms to submit periodical reports as required by ZEMA. Occasionally, some firms have dumped toxic waste materials into local streams to save disposal costs accruing contamination in the Kafue since all these streams eventually drain down the entire load into the Kafue main river which is a major source of agriculture and domestic water supply, from Chililabombwe through Chingola, Mufulira, Kitwe, and all the way to Lusaka.

Thus, although wastewater quality compliance has generally improved, there were still cases of hazardous chemical waste discharge by some firms to gain savings from the expenses that would otherwise have been incurred through normal disposal procedures, even if the savings could be far less than the penalties they would incur if convicted. Such unethical companies are motivated to engage in such illegal activities for profit, having known that the probability of being caught is negligible due to poor monitoring, while conviction is difficult due to problems facing the judicial system where cases drag-on for decades in court.

Secondary data and field observations (Figure 2) suggest that there is poor management of mine waste dumps and tailing dams. Most of the waste dumps are unstable and are the main sources of siltation on the Kafue River, reducing the water flow and the river channel. Mining and erosion of unstable waste dumps and tailing dams on the Copperbelt contribute about 135,000 tonnes per year to the siltation problems in the local streams-drainage-system on one hand, while on the other, the landforms where these dumps rest may be difficult to put to any alternative land-use, thereby potentially depriving the nation of future economic activities [10].

Conversely, records from the year 2000 onwards clearly indicated that copper smelting alone has been contributing about 350,000 tonnes of $\mathrm{SO}_{\mathrm{x}}$ annually, with concentration ranging from $500-1000 \mu \mathrm{gm}^{-3}[10]$. These daily concentrations are 10 to 20 times more than the regulatory limits. Mining firms are also failing to submit periodic reports as required under their permits on air quality, probably due to lack of compliance. While the mining firms were found to be concerned about good corporate citizenship, the environmental protection commitment of most of them (80\%) was found to be weak, and lacked specific goals. This was evidenced by the use of old and un-updated ESMPs, and lack of certification with Environmental Management Systems; i.e., ISO 14001 standards.

Although monitoring for compliance by the regulatory agencies was found to be poor, Zambia has probably one of the strongest environmental regulations in the region. Thus, although it only emerged in the 1970s, the environmental regimes in Zambia compare very well with that of developed nations like the United Kingdom [7] to the point where this has been seen as anti-development by some critics. For instance, some neo-classical frontiers economists now argue that Zambia is introducing anti-development environmental agendas, by slowly making the environmental area among the most highly regulated sectors in the world which may increase the cost of doing business. Because of such criticisms, the
Zambian government reactions often end up in allowing projects in ecologically sensitive areas [25]. However, these arguments lack validity in view of causes of market failure: most environmental problems can be understood as resulting from market failures, where the most relevant type is negative externality. To overcome negative externality, polluters must pay for the pollution damage. It has been proven globally in many studies, that when companies comply and go greener in their operations further than what the regulations have prescribed, there is less regulation in return, and less policing by government as a result $[4,9,18,19,20,21$, $22,23,24]$. This does not only improve the company's reputation, but also reduce the costs of doing business [26, 27]. In Zambia, while the regulations can be considered as tough, the means for implementing these regulations is weak, as well as the means for measuring policy outcomes are unclear. A further challenge is the lack of resources and capacity to drive these environmental strategies for the desired outcomes. The institutional framework lacks co-ordination, which makes it difficult to implement strategies that cut across related sectors such as lands, environment, agriculture, water, forestry and energy. These findings are consistent with those by [10], who also found that co-ordination even within the same regulatory framework was weak. The conclusions are clear.

Selective application of the Environmental Impact Assessment (EIA) regulations exists. State owned and government backed projects are 3 to 4 times more likely to get approvals even with very poor quality Environmental Impact Statements (EIS). The EIA process and the EIA practitioners in Zambia do not adhere to professionalism and the demands of environmental justice. Abuse of office also does exist within ZEMA as some employees conduct environmental projects briefs (EPBs) and approve them themselves.

Government commitment to environmental protection has fluctuated over the last decade, as evidenced by the funds allocated towards the sector. Much of the funding in the sector comes from donor countries. As argued by [28, 29], to make policy effective, it must be designed carefully with clearly measurable goals. Funds must be available for its effective implementation, then that must be reinforced by government will, and the capacity to measure policy outcomes. Thus, going by the findings, it can be concluded that the implementation of Zambia's environmental regulatory regime cannot achieve desired outcomes with such a wide range of problems, from a centralized system, through to lack of funds and material resources, and from lack of technical personnel capacity to enforce and measure policy outcomes to unclear goals. If these can be dealt with, driving environmental sustainability agenda would probably be much easier to achieve since there is already enough and well designed regulations in place. It can also be concluded that there are no clear market-based instruments (MBIs) for firms. MBIs such as environmental tax breaks, tradable permit systems or targeted subsidies are a cost-effective way to protect and improve the environment as these provide incentives to both firms and consumers to opt for cleaner production and greener products respectively [30]. 
While it is concluded that the Environmental Protection Fund (EPF) is one of the most successive stories of the Copperbelt Environment Project (CEP), it can be further said that the EPF still has challenges in objectively costing environmental liabilities of mining firms as well as enforcing compliance. Mining firms are simply not complying enough. While issues of surety, trust and transparency have been raised by these firms, most of them (70\%) have 2 to 3 years arrears and are thus not up-date with EPF contributions and bank guarantees [31]. The contributions are very little compared to the environmental degradation caused. The current quantum method needs to be improved so that it reflects actual liabilities of any given firm in the extractive industry, including small scale mining companies, as these can be among some of the major sources pollution. The pool funds contributed are far too insufficient to manage the environmental damages of the associated mining activities. Environmental clean-ups can be very costly as evidenced in the CEP implementation.

Finally, all measures that have been put in place by government to ensure that the environmental degradation caused by mining activities are adequately managed, are not working effectively. There is still weak enforcement. These findings are generally consistent with the findings of the 2014 Auditor General's Report on Mining in Zambia.

\section{References}

[1] P. Modak and A. K. Biswas, Conducting environmental impact assessment for developing countries, New York, United Nations University Press, 1999.

[2] Organization for Economic Corporation and Development, Environmental outlook to 2050 report, OEC, 2011.

[3] DfID, EC, UNDP and Word Bank, Linking poverty reduction and environmental management: policy challenges and opportunities. Washington DC. The World Bank, 2002.

[4] International Panel for Sustainable Resource Management, Marrakech process and green economy initiative: working towards a sustainable consumption and production for a green economy: UNEP, 2010.

[5] http://www.equator-principles.com: Accessed 26 May 2015

[6] International Council on Mining and Metals Report on Zambia, 2014

[7] C. Makondo, Environmental Impact Assessment: a comparative analysis of the UK and the Zambian regulations (MSc Dissertation) 2009, Institute of Estuarine and Coastal Studies, University of Hull, United Kingdom.

[8] E.M. De Santo, Missing marine protected area (MPA) targets: How the push for quantity over quality undermines sustainability and social justice, Journal of Environmental Management Vol.124. 2013, pp.137-146.

[9] The Business of Sustainability: Building industry cases for corporate responsibility, Edited by Ulrich Steger, 2004.

[10] J.Lindahl, Environmental impacts of mining in Zambia: Towards better environmental management and sustainable exploitation of mineral resources, 2014, Geological Survey of Sweden.

[11] E.F. Lambin and P. Meyfroidt. Global land use change, economic globalization and looming land scarcity: proceeding of the National Academy of Sciences (USA) 108: 3465-3472, 2011.

[12] World Business Council for Sustainable Development, Effective biodiversity and ecosystem policy and regulation: business input to the COP10 of Convention on Biological Diversity. WBCSD, Geneva, 2010.

[13] L. Xianbing, B, Liu , T. Shishime, Q. Yu, J. Bi, and T. Fujitsuka, An empirical study on the driving mechanism of proactive corporate environmental management in China, Journal of Environmental Management, vol, 91, 2010, pp.1707-1717.

[14] D.G. Fraser, J. Andrew Dougill, W.E. Mabee, M. Reed. P McAlpine, Bottom up and top down: Analysis of participatory processes for sustainability indicator identification as a pathway to community empowerment and sustainable environmental management, Journal of Environmental Management Vol. 78 2006, pp.114-127.

[15] A.A .Hezri, Sustainability indicator system and policy processes in Malaysia: a framework for utilization and learning, Journal of Environmental Management, Vol. 73, 2004, pp.357-371.

[16] K. Zhang, and Z. Wen, Review and challenges of policies of environmental protection and sustainable development in China, Journal of Environmental Management, Vol. 88, 2008, pp. 1249-1261.

[17] R.G. Eccles, I. Ioannou, I., and G. Serafeim, The impact of corporate culture of sustainability on corporate behavior and performance- working paper, 2012.

[18] E. G., Hertwich, W. S. Pease, and C. P. Koshland, "Evaluating the environmental impact of productsand production processes: A comparison of six methods," Science of the Total Environment, 196, 1997. Pp.13-29.

[19] G., Winter, Business and the environment: A handbook of industrial ecology, Hamburg: 1988, McGraw-Hill.

[20] D., O'Rourke, L. Connelly, and C. P. Koshland, "Industrial ecology - a critical review," International Journal of Environmental Pollution 6 (2-3), 1996. Pp.89-112.

[21] E., Matthews, C. Amann, M. Fischer-Kowalski, S. Bringezu, W. Hüttler, R. Kleijn, Y. Moriguchi, C. Ottke, E. Rodenburg, D. Rogich, H. Schandl, H. Schütz, E. van der Voet, and H. Weisz, The weight of nations: Material outflows from industrial economies, Washington, DC: 2000. World Resources Institute.

[22] S., Nakamura and Y. Kondo, "Input-output analysis of waste management," Journal of Industrial Ecology, 6 (1), 2002, pp. 39-64.

[23] Duchin, F., "The conversion of biological materials and wastes to useful products," Structural Change and Economic Dynamics, 1(2), 1990, pp.243-261.

[24] C. J., Cleveland, "Biophysical economics: From physiocracy to ecological economics and industrial ecology," in J. Gowdy and K. Mayumi, eds. Bio-economics and Sustainability: Essays in Honor of Nicholas Gerogescu-Roegen, Cheltenham, England: 1999. Edward Elgar Publishing, pp.125-154 
[25] http://zambia.co.zm/zol articles/2014/02/16/reframing-the-lo wer-zambezi-copper-mining-project-debate.accessed 6/2/2015

[26] S., Erkman, "Industrial ecology: a historical view," Journal of Cleaner Production, 5(1-2), 1997, pp. 1-10.

[27] Duchin, F., and G. Lange, The Future of the Environment: Ecological Economics and Technological Change, 1994. New York: Oxford University Press

[28] J. Mitchell, "The Use (and Misuse) of Surveys in Policy Analysis," in Handbook of Public Policy, 2007.
[29] A. Gilbert, Criteria for sustainability in the development of indicators for sustainable development, Chemosphere: Elsevier Science, No. 9, vol. 33, 1996, pp.1739-1748.

[30] http://ec.europa.eu/environment/enveco/studies.htm\#2 accessed, 6/2/2015.

[31] GRZ, Management of Environmental Degradation Caused by Mining Activities in Zambia. Auditor General's Report, 2014, Government of the Republic of Zambia (GRZ). 